\title{
OPTIMALISASI BADAN PENYELESAIAN SENGKETA KONSUMEN TERHADAP SENGKETA PINJAMAN KREDIT KENDARAAN BERMOTOR DI WILAYAH BOGOR BERDASARKAN UNDANG-UNDANG PERLINDUNGAN KONSUMEN
}

\section{OPTIMIZATION OF CONSUMER DISPUTE SETTLEMENT AGENCY ON DISPOSAL OF MOTOR VEHICLE LOAN IN BOGOR AREA BASED ON LAW CONSUMER PROTECTION} Edy Sanjaya Lase dan
Muhammad Taufiq

\author{
Program Studi Ilmu Hukum Sekolah Pascasarjana \\ Universitas Djuanda Bogor \\ Jl. Tol Ciawi No. 1, Kotak Pos 35, Bogor 16720. \\ Korespondensi : Edy Sanjaya Lase, Telp. - \\ e-mail :
}

Jurnal Living Law, Vol. 10, No.

2 , 2018 hlm. 155171

\begin{abstract}
The purpose of this study are to find out and analyze the optimization of the Consumer Dispute Settlement Agency against disputes in motor vehicle credit loans in the Bogor region based on Law Number 8 of 1999 concerning Consumer Protection, and also the inhibiting factor in the optimization of BPSK against disputes in motor vehicle loan loans. The research method used in this study is normative juridical research that takes a qualitative approach. The results of this study are: the role of BPSK on disputes over motor vehicle credit loans is not optimal, it is necessary to optimize efforts for BPSK to become a fast, inexpensive and fair consumer-focused settlement institution outside the court. The inhibiting factor is the optimization of the Bogor City BPSK and Bogor Regency against disputes on motorized vehicle loans, including legislation and resources. BPSK is shackled by very complex regulations in the UUPK, even some UUPK articles actually contradict each other. Resource constraints include human resources, infrastructure and budgeting.
\end{abstract}

Keywords : BPSK, Consumer Protection, loan.

\begin{abstract}
Abstrak : Tujuan penelitian ini yaitu untuk mengetahui dan menganalisis optimalisasi Badan Penyelesaian Sengketa Konsumen (BPSK) terhadap sengketa pinjaman kredit kendaraan bermotor di wilayah Bogor berdasarkan Undangundang Nomor 8 Tahun 1999 tentang Perlindungan Konsumen, serta faktor penghambat dalam optimalisasi BPSK terhadap sengketa pinjaman kredit kendaraan bermotor. Metode penelitian yang digunakan dalam penelitian ini adalah penelitian yuridis normatif yang melakukan pendekatan kualitatif. Hasil dari penelitian ini yaitu: peran BPSK terhadap sengketa pinjaman kredit kendaraan bermotor belum optimal, maka perlu upaya-upaya optimalisasi agar BPSK dapat menjadi lembaga penyelesaian sengeta konsumen di luar pengadilan yang cepat, murah, dan adil. Faktor penghambat optimalisasi BPSK Kota Bogor dan Kabupaten Bogor terhadap sengketa pinjaman kredit kendaraan bermotor, meliputi peraturan perundang-undangan dan sumber daya. BPSK terbelenggu dengan peraturan yang sangat rumit dalam UUPK, bahkan beberapa pasal UUPK justru saling bertentangan. Kendala sumber daya meliputi baik sumber daya manusia maupun infrastruktur dan penganggaran.
\end{abstract}

Kata Kunci : BPSK, Perlindungan Konsumen, pinjaman. 


\section{PENDAHULUAN}

Berkembangnya

perekonomian nasional telah membawa perkembangan di bidang perdagangan yang menghasilkan variasi produk barang dan/atau jasa yang dapat dikonsumsi. Perluasan ruang gerak transaksi barang dan/atau jasa semakin didukung oleh kemajuan di bidang ilmu pengetahuan dan teknologi hingga melintasi batas-batas suatu negara. Kondisi tersebut di satu sisi menguntungkan konsumen karena kebutuhannya akan barang dan/atau jasa yang diinginkan dapat terpenuhi serta bisa memberikan kebebasan pada konsumen untuk memilih kualitas barang dan/atau jasa sesuai keinginan dan kemampuannya.

Di sisi lain, fenomena tersebut mengakibatkan kedudukan pelaku usaha dan konsumen menjadi tidak seimbang. Konsumen berada pada kedudukan yang lemah. Selain itu, konsumen juga dapat menjadi objek aktivitas bisnis untuk mendapatkan keuntungan yang besar oleh pelaku usaha melalui promosi, penjualan, dan penerapan perjanjian standar yang merugikan konsumen. Hal ini disebabkan oleh kurangnya pendidikan konsumen serta rendahnya kesadaran konsumen akan hak-haknya.

Selain itu, dalam setiap aktivitas perdagangan pada umumnya pihak konsumen berada pada posisi tawar yang lebih lemah dibandingkan pelaku usaha sehingga konsumen kadang-kadang tidak dapat berbuat banyak ketika kondisi barang yang mereka terima tidak sesuai dengan yang ditawarkan oleh pelaku usaha. Melihat kondisi tersebut maka harus ada instrumen yang mampu melindungi kepentingan-kepentingan konsumen yang selama ini terabaikan. Oleh karena itu, untuk dapat menjamin suatu penyelenggaraan perlindungan konsumen, maka pemerintah menuangkan perlindungan konsumen dalam UndangUndang Nomor 8 Tahun 1999 tentang Perlindungan Konsumen yang mengatur tentang hak dan kewajiban masing-masing pihak (dalam hal ini konsumen dan pelaku usaha) begitu pula larangan-larangannya hingga mekanisme penyelesaian sengketa.

Lahirnya Undang-Undang Nomor 8 Tahun 1999 tentang Perlindungan Konsumen yang disahkan dan diundangkan pada tanggal 20 April 1999, dan berlaku secara efektif tanggal 20 April 2000 mengatur antara lain keberadaan lembaga penyelesaian sengketa konsumen di luar pengadilan yang disebut dengan Badan Penyelesaian Sengketa Konsumen (BPSK). Pembentukan BPSK ini dilatarbelakangi adanya globalisasi dan perdagangan bebas, yang didukung kemajuan teknologi dan informatika dan dapat memperluas ruang gerak transportasi barang dan/atau jasa melintasi batas-batas wilyah suatu negara.

Untuk mengatur kelembagaan BPSK tersebut telah dikeluarkan sejumlah peraturan perundang-undangan sebagai berikut: 1

1. Keputusan Presiden Nomor 90 Tahun 2001 tentang Pembentukan Badan Penyelesaian Sengketa Konsumen (BPSK).

2. Keputusan Menteri Perindustrian dan Perdagangan Nomor 301 MPP/Kep./10/2001 tanggal 24 Oktober 2001 tentang Pengangkatan dan Pemberhentian Anggota dan Sekretariat BPSK.

3. Keputusan Menteri Perindustrian dan Perdagangan Nomor 302 MPP/Kep./10/2001 tanggal 24 Oktober 2001 tentang Pendaftaran Lembaga Perlindungan Konsumen Swadaya Masyarakat (LPKSM).

4. Keputusan Menteri Perindustrian dan Perdagangan Nomor 350/MPP/Kep./12/2001 tanggal 10 Desember 2001 tentang Tugas dan Wewenang Badan Penyelesaian Sengketa Konsumen.

5. Surat Keputusan Menteri Perindustrian dan Perdagangan Nomor 605/MPP/Kep./8/2002 tanggal 29 Agustus 2002 tentang Pengangkatan

1 Suherdi Sukandi, Fungsi dan Peranan Dalam Penyelesaian Sengketa Konsumen, Semiloka UUPK dan BPSK Kota Bandung, Bandung 29 Mei 2004. 
Anggota Badan Penyelesaian Sengketa Konsumen.

Sesuai Pasal 45 ayat (1) Undangundang Nomor 8 Tahun 1999 tentang Perlindungan Konsumen, ditentukan bahwa setiap konsumen yang dirugikan dapat menggugat pelaku usaha melalui lembaga yang bertugas menyelesaikan sengketa antara konsumen dan pelaku usaha atau melalui peradilan yang berada di lingkungan peradilan umum.

Berdasarkan Pasal 45 ayat (2) Undangundang Nomor 8 Tahun 1999 tentang Perlindungan Konsumen, bahwa penyelesaian sengketa konsumen dapat ditempuh melalui pengadilan atau di luar pengadilan berdasarkan pilihan sukarela para pihak yang bersengketa.

Dari ketentuan tersebut di atas dapat diketahui bahwa para pihak yang bersengketa diberi hak untuk memilih lembaga atau badan mana yang akan mereka pilih untuk menyelesaikan permasalahan yang mereka hadapi baik melalui jalur pengadilan maupun jalur luar pengadilan, untuk jalur pengadilan pengertiannya adalah pengadilan umum, sedangkan sesuai Pasal 45 ayat (1) Undang-undang Nomor 8 Tahun 1999 tentang Perlindungan Konsumen, yang telah disebut terdahulu oleh peneliti. Penyelesaian sengketa konsumen jalur luar pengadilan dilaksanakan di dalam suatu lembaga yang dibentuk berdasarkan Pasal 49 ayat (1) Undang-undang Nomor 8 Tahun 1999 tentang Perlindungan Konsumen, yaitu bahwa pemerintah membentuk badan penyelesaian sengketa konsumen di Daerah Tingkat II untuk menyelesaikan sengketa konsumen di luar pengadilan. Dengan demikian, Badan Penyelesaian Sengketa Konsumen-lah yang ditunjuk pemerintah sebagai lembaga yang dapat menyelesaikan sengketa konsumen di luar pengadilan.

Tidak dapat dipungkiri, bahwa dalam praktik-praktik perdagangan (baik ketika proses perdagangan maupun setelah proses perdagangan terjadi) banyak ditemui akan adanya suatu pelanggaran- pelanggaran terhadap apa yang menjadi hak konsumen (sebagai pengguna barang dan/atau jasa) ataupun pelanggaran pelaku usaha ketika menawarkan dan menjualkan produk kepada konsumen, sehingga akhirnya konsumen berminat sampai pada akhirnya mengkonsumsi produk yang ditawarkan tersebut.

Ada beberapa contoh yang telah terjadi pada tahun 2016, seperti terjadi kenaikan Bahan Bakar Minyak (BBM), listrik dan telepon yang dipandang membebani masyarakat. Kenaikan mengakibatkan gejolak antara pemerintah dengan masyarakat sebagai konsumen BBM dan pelanggan listrik serta telepon, diketahui ternyata pemerintah pernah berjanji kepada masyarakat tetapi jarang ditepati, seperti tidak adanya jaminan jika aliran listrik mati tidak mengenal waktu dan kemudian petugas Perusahaan Listrik Negara (PLN) akan cepat menghidupkan. Belum lagi saling tuding tentang permainan meteran yang sering merugikan konsumen. ${ }^{2}$

Selain itu, ada kegiatan perdagangan seperti promosi atau penawaran kepada konsumen yang dilakukan oleh pelaku usaha untuk menarik minat konsumen dengan memberikan berbagai hadiah menarik, dan belakangan ini penawaran dengan cara seperti itu oleh pelaku usaha dilakukan dengan memberikan hadiah terhadap penjualan produk khususnya barang. Kemudian konsumen dinyatakan sebagai pemenang dan berhak mendapatkan hadiah serta harus diambil langsung di tempat dan tidak boleh diwakilkan. Masalah yang timbul di kemudian hari ternyata konsumen ingin membatalkan kontrak jual-beli dengan mengembalikan barang-barang tersebut, namun yang terjadi barang diterima pelaku usaha tetapi uang yang sudah dibayar tidak dikembalikan. ${ }^{3}$

\footnotetext{
2 Suara Merdeka, Menyoal Kepedulian Konsumen, 07/01/2016, \& Jawa Pos, Janji Indah Itu Hanya Basa-basi, 16/01/2016.

3 Kompas, Kritis Menghadai Trik dagang, 04/03/2016.
} 
Contoh kasus berkaitan dengan developer atau pengembang seperti di Semarang, Jawa Tengah beberapa waktu yang lalu dimana pada waktu itu Perumahan Bukit Indah Regency Srondol yang longsor tahun 2016, ternyata merugikan konsumen. Kemudian kasus lain serupa terjadi lagi tahun 2016 yang pada akhirnya 100 (seratus) penghuni Perumahan Taman Setia Budi (TBS), Srondol Wetan Banyumanik Semarang memprotes PT. Karya Alvita Nawatama (KAN), pengembang perumahan itu. Dalam hal ini yang diprotes oleh 100 (seratus) penghuni tersebut adalah setelah mereka yang menjadi penghuni/pemilik rumah kelas menengah dan atas selaku konsumen memprotes tentang Sertifikat Hak Milik (SHM) atas rumah yang telah dibayar, ini terjadi karena selama 4 (empat) tahun konsumen diombang-ambingkan pihak pengembang dalam masalah sertifikat rumah tersebut. ${ }^{4}$ Banyak lagi contohcontoh kasus berkaitan dengan pelanggaran terhadap hak-hak konsumen yang dilakukan oleh pelaku usaha.

Melalui kasus-kasus di atas dapat dipahami bahwa keberadaan Badan Penyelesaian Sengketa Konsumen (BPSK) sebagai badan yang dibentuk secara khusus oleh pemerintah dalam rangka membantu masyarakat untuk penyelesaian persoalanpersoalan tentang sengketa konsumen harus lebih diketahui oleh masyarakat secara luas, agar masyarakat memiliki gambaran bagaimana menyelesaikan persoalan jika mereka selaku konsumen menghadapi kekecewaan atau ketidakpuasan atau bahkan penipuan dari pelaku usaha atas barang dan/atau jasa yang telah konsumen beli dengan membayarkan uang dalam jumlah tertentu sehingga tidak mengalami banyak kerugian.

Berdasarkan hasil penelitian di Badan Penyelesaian Sengketa Konsumen Kota Bogor, diperoleh informasi bahwa saat ini tidak sedikit dari pihak pelaku usaha yang

4 Kompas, Developer Jangan Bohongi Konsumen, $17 / 02 / 2016$ dalam melakukan usahanya untuk menarik perhatian dari konsumen dengan memberikan jaminan tertentu terhadap konsumen seperti halnya ketika ada seorang konsumen yang membeli secara kredit/tidak tunai/angsuran membeli kendaraan kemudian pelaku usaha menyajikan dan menawarkan kepada konsumen adanya perjanjian yang dalam kontrak/perjanjian tersebut dicantumkan untuk menjadi pilihan sehingga harus disepakati oleh kedua belah pihak yaitu antara konsumen dengan pelaku usaha. ${ }^{5}$

Kontrak/perjanjian tersebut salah satunya berisi tentang jaminan dari konsumen kepada pelaku usaha berupa benda bergerak yaitu Buku Pemilikan Kendaraan Bermotor (BPKB). Atau bahkan jaminan berupa benda tidak bergerak. Hal ini disebabkan karena dalam perjanjian/kontrak terdapat klausula yang menyebutkan jaminan fidusia. Pelaku usaha menjanjikan penandatanganan kontrak di hadapan notaris, tetapi setelah transaksi ternyata hal tersebut tidak dilakukan. Dan ketika konsumen wanprestasi, belum ada titik terang penyelesaian.

Sebagai contoh kasus bahwa PT MITRA PINASTHIKA MUSTIKA FINANCE, Tergugat/Pelaku Usaha melawan PETO SYAMSUL ALAM, Penggugat/Konsumen. Bahwa Tergugat/Pelaku Usaha telah mengajukan keberatan terhadap Putusan Arbitrase Badan Penyelesaian Sengketa Konsumen Kota Bogor Nomor 20/Pts.BPSK/XII/2012 tanggal 14 Desember 2012.

Bahwa, terhadap amar Putusan Arbitrase Badan Penyelesaian Sengketa Konsumen Kota Bogor tersebut, Tergugat/Pelaku Usaha telah mengajukan keberatan di depan persidangan Pengadilan Negeri Bogor yang pada pokoknya sebagai berikut:

1) Bahwa putusan Arbitrase BPSK Bogor tersebut telah diberitahukan oleh kepaniteraan BPSK Bogor pada tanggal 
24 Desember 2012 di kantor cabang Pemohon keberatan di Bandung dan ditindaklanjuti dengan penyampaian keberatan ini pada tanggal 3 Januari 2013 dimana masih dalam batas tenggang waktu 14 hari kerja yang dipersyaratkan dalam Pasal 56 ayat (2) Undang-undang Nomor 8 Tahun 1999 tentang Perlindungan Konsumen.

2) Bahwa Pemohon sangat keberatan dengan pertimbangan hukum maupun putusan Majelis BPSK Kota Bogor dalam perkara a quo karena Majelis BPSK Bogor telah menyimpangi acara yang berlaku di hadapan Majelis Arbitrase, menyimpangi tugas dan wewenang BPSK sendiri dan telah menerapkan hukum tidak sebagaimana mestinya.

Keberadaan Badan Penyelesaian Sengketa Konsumen (BPSK) saat ini sudah mengalami perkembangan karena sudah semakin banyaknya masyarakat yang mulai mengenal BPSK walaupun masih diperlukan publikasi lagi. Berkembangnya BPSK terbukti dari semakin bertambahnya BPSK di beberapa kabupaten atau kota di Indonesia, saat BPSK kali pertama dibentuk oleh pemerintah tahun 2001-an ada 10 (sepuluh) Kota/Kabupaten yang memiliki BPSK sedangkan sekarang ternyata sudah ada lebih kurang 25-an (dua puluh limaan) BPSK di Kota/Kabupaten di Indonesia. Sedangkan secara yuridis aturan-aturan yang mengatur tentang BPSK sendiri ada yang masih dirasakan BPSK kurang efisien/efektif bahkan tidak menutup kemungkinan juga pernah mengalami permasalahan atau kendala yang secara tidak langsung dapat menjadi bagian yang harus diperhatikan oleh pihak BPSK Kota Bogor dalam proses penyelesaian sengketanya.

Berdasarkan penelitian, diperoleh jumlah pengaduan sengketa konsumen yang telah masuk di BPSK Kota Bogor cukup banyak dan dengan berbagai macam pengaduan yang ada antara lain: ada yang bersifat konsultasi, tetapi ada juga yang pengaduannya tersebut selanjutnya bersifat permohonan penyelesaian sengketa melalui BPSK. ${ }^{6}$

Dari sengketa yang ada ketika para pihak yang bersengketa memilih penyelesaian sengketa di luar peradilan yaitu BPSK, maka pihak yang bersengketa secara otomatis memilih penyelesaian sengketa melalui BPSK, dengan demikian pihak yang bersengketa berkewajiban untuk memilih cara penyelesaian yang ada dan/atau yang tersedia/ditentukan di BPSK, yaitu metode mediasi atau konsiliasi atau arbitarase yang merupakan metode penyelesaian sengketa konsumen sesuai dengan peraturan perundang-undangan terutama Undang-undang Perlindungan Konsumen serta harus berdasarkan dari kesepakatan para pihak yang bersengketa tersebut.

Menurut Undang-undang Nomor 8 Tahun 1999 tentang Perlindungan Konsumen Pasal 52 huruf a, BPSK selaku badan atau lembaga saat ini bertugas dan berwenang dalam menyelesaikan sengketa konsumen yang terjadi mempunyai beberapa cara penyelesaian atau sering disebut dengan metode penyelesaian sengketa yang antara lain adalah mediasi atau arbitrase atau konsiliasi.

Secara singkat/garis besarnya sebagai berikut:

1. Melalui metode mediasi yaitu dalam penyelesaian sengketa konsumen di luar pengadilan melalui cara ini pada dasarnya sama dengan cara konsiliasi, hanya yang membedakan dari kedua cara dimaksud bahwa majelis aktif dengan memberikan nasehat, petunjuk, saran dan upaya lain dalam penyelesaian sengketa, namun demikian hasil keputusan seluruhnya diserahkan kepada para pihak.

2. Melalui metode arbitrase yaitu dalam penyelesaian sengketa konsumen di luar pengadilan melalui cara ini, pelaksanaannya berbeda dengan cara mediasi dan konsiliasi. Majelis bertindak aktif untuk mendamaikan 
para pihak yang bersengketa. Bilamana tidak tercapai kesepakatan, cara persuasif tetap dilakukan dengan memberi penjelasan kepada para pihak yang bersengketa perihal peraturan perundang-undangan di bidang perlindungan konsumen. Keputusan atau kesepakatan dalam penyelesaian sengketa sepenuhnya menjadi wewenang majelis.

3. Melalui metode konsiliasi yaitu dalam penyelesaian sengketa konsumen di luar pengadilan melalui cara ini, bahwa majelis berupaya untuk mendamaikan para pihak yang bersengketa, jika melalui cara ini majelis hanya bertindak sebagai konsiliator (pasif). Hasil penyelesaian sengketa konsumen tetap berada di tangan para pihak.

Pemilihan metode penyelesaian sengketa dengan cara mediasi atau konsiliasi atau arbitrase sepenuhnya diserahkan kepada para pihak yang bersengketa untuk memperoleh keputusan atau kesepakatan untuk menentukan baik bentuk maupun jumlah ganti rugi yang harus diterima oleh konsumen, dengan kesepakatan yang akan dituangkan dalam perjanjian tertulis dan ditandatangani oleh kedua belah pihak yang bersengketa, sebagai bukti untuk pembuatan berita acara oleh panitera Badan Penyelesaian Sengketa Konsumen.

Berdasarkan latar belakang masalah di atas, maka penulis dapat mengidentifikasi masalah sebagai berikut:

1. Bagaimana optimalisasi Badan Penyelesaian Sengketa Konsumen (BPSK) terhadap sengketa pinjaman kredit kendaraan bermotor di Kota Bogor dan Kabupaten Bogor berdasarkan Undang-undang Nomor 8 Tahun 1999 tentang Perlindungan Konsumen?

2. Bagaimana faktor penghambat dalam optimalisasi Badan Penyelesaian Sengketa Konsumen (BPSK) terhadap sengketa pinjaman kredit kendaraan bermotor di Kota Bogor dan Kabupaten Bogor berdasarkan Undang-undang
Nomor 8 Tahun 1999 tentang Perlindungan Konsumen?

\section{METODE PENELITIAN}

Metode penelitian yang digunakan dalam penelitian ini adalah pendekatan yuridis normatif, yaitu hukum dikonsepsikan sebagai norma, kaidah, asas atau dogma-dogma/yurisprudensi.

\section{PEMBAHASAN}

\section{A. OPTIMALISASI PENYELESAIAN KONSUMEN (BPSK) TERHADAP SENGKETA PINJAMAN KREDIT KENDARAAN BERMOTOR DI KOTA BOGOR DAN KABUPATEN BOGOR BERDASARKAN UNDANG-UNDANG NOMOR 8 TAHUN 1999 TENTANG PERLINDUNGAN KONSUMEN}

Dalam era globalisasi, dunia seakan menuju pada satu sistem yakni sistem suatu negara yang dominan. Dinamika kebijakan perekonomin negara-negara di dunia tidak dapat dilepaskan pada pusaran arah tersebut. Negara-negara yang dulunya memiliki sistem perekonomian sosialis saat ini mengarah pada liberalis-kapitalis. Dalam pergolakan dinamika seperti ini, setiap negara harus mampu mengambil sikap kalau tidak ingin terbawa dan terseret arus globalisasi. Namun menarik apa yang dikemukakan oleh George Soros, bahwa sistem kapitalisme global yang berlaku sekarang adalah bentuk menyimpang (distorsi) dari masyarakat terbuka. Sistem kapitalis tersebut terlalu banyak memberi bobot pada motif profit dan persaingan tapi gagal melindungi kepentingan umum melalui pembuatan keputusan kooperatif. ${ }^{7}$

Dalam konteks pembangunan hukum ekonomi, termasuk hukum perlindungan konsumen sebagai salah satu bagiannya, yang mendasarkan pada aturan dasar

7 Esmi Warassih, Pranata Hukum Sebuah Telaah Sosiologis, Semarang: Badan Penerbit UNDIP, 2011, Hlm. 15. 
(politik hukum dasar) UUD 1945, perundang-undangan yang sudah, sedang dan akan disusun harus berlandaskan pada nilai-nilai Pancasila. Sehingga harus terdapat koherensi, konsistensi, dan korespondensi antara perundangundangan yang akan disusun, dengan nilainilai yang terkandung dalam Pancasila. Koherensi diartikan kepaduan makna. Konsistensi dapat diartikan tidak mengandung kontradiksi. Norma yang dibuat dalam perundang-undangan tidak mengandung kontradiksi dengan nilai-nilai Pancasila. Sedangkan korespondensi yaitu adanya hubungan antara peraturan yang satu dengan yang lain, termasuk peraturan yang lebih tinggi tingkatnya. Koherensi dan korespondensi terhadap produk undangundang merupakan sarana bagi terwujudnya kesesuaian produk tersebut dengan dasar/falsafah negara Pancasila dan fakta empiris masyarakat Indonesia.

Hukum perlindungan konsumen sebagai bagian dari hukum ekonomi, perlu mendapatkan perhatian serius dari negara mengingat tantangan di era global yang semakin kuat. Globalisasi menjadikan kegiatan-kegiatan ekonomi semakin beragam dan melewati batas-batas teritorial negara. Kegiatan investasi, industri dan perdagangan dengan mudah masuk ke suatu negara, tidak terkecuali Indonesia. Dengan jumlah penduduk yang sangat besar, Indonesia dipandang sebagai pasar yang sangat potensial untuk memasarkan produk barang atau jasa.

Di sisi lain, kondisi masyarakat (konsumen) Indonesia sangat heterogen baik dari segi pendidikan, kemampuan ekonomi, maupun tingkat kesadaran hukumnya. Tugas utama pengemban hukum, baik dalam aras legislasi, yudikasi maupun eksekusi, adalah mengidentifikasi dan mewujudkan suatu bonum commune. Tujuan dan kebaikan bersama seluruh rakyat Indonesia telah dirumuskan dalam Pancasila dan UUD 1945. Oleh karenanya diperlukan pembangunan sistem hukum perlindungan konsumen yang kuat dengan didukung dengan politik hukum ekonomi yang berlandaskan pada Pancasila dan UUD 1945.

Hasil evaluasi Badan Perlindungan Konsumen Nasional (BPKN) tahun 2017 menyebutkan adanya kekurangan yang terkandung di dalam UUPK sehingga menjadi hambatan dalam penerapan dan penegakan UUPK. Hambatan yang dimaksud antara lain: ${ }^{8}$

a. Pengertian konsumen akhir yang tidak jelas, sehingga menimbulkan beragam penafsiran dalam penerapan dan penegakan UUPK;

b. Penyamaan pengertian kata 'memproduksi' dan 'memperdagangkan' yang memiliki pengertian dan jenis tanggung jawab hukum yang berbeda, sehingga terjadi kekisruhan dalam penerapan dan penegakan UUPK;

c. Pengertian klausula baku yang tidak jelas dan pengaturan akibat hukum penggunaan klausula baku yang keliru, sehingga menimbulkan beragam penafsiran dalam penerapan dan penegakan UUPK;

d. Ketidakjelasan pengaturan koordinasi antar berbagai instansi penegak hukum yang terlibat dalam penegakan UUPK, yaitu antar Departemen terkait, Badan Penyelesaian Sengketa Konsumen (BPSK), Kepolisian, Kejaksaan, dan Pengadilan;

e. BPSK tidak diberi wewenang untuk mengeksekusi putusannya, melainkan harus dimintakan fiat eksekusi pada pengadilan negeri;

f. Walaupun putusan BPSK bersifat final dan mengikat (final and binding), ternyata UUPK memberi peluang kepada para pihak yang tidak menerima putusan BPSK untuk mengajukan keberatan atas putusan tersebut ke pengadilan negeri;

g. Badan Perlindungan Konsumen Nasional (BPKN) hanya berfungsi sebagai badan penasehat (advisory body), sehingga tidak memiliki fungsi 
koordinatif dalam penerapan dan penegakan UUPK.

Tantangan lain yang perlu mendapat perhatian adalah kemampuan UUPK dalam menghadapi arus globalisasi dan/atau regionalisasi yang semakin sukar dihindari. Bagaimana ke depan UUPK akan mengatur tentang keberlakuan UUPK di dalam wilayah Hukum Negara RI dan di luar wilayah Hukum Negara RI bagi konsumen dan pelaku usaha warga negara Indonesia. Keberlakuan UUPK di dalam wilayah Hukum Negara RI didasarkan pada asas non diskriminasi atau asas persamaan, sehingga tidak terdapat perbedaan keberlakuan UUPK bagi konsumen

dan pelaku usaha asing yang berada di Indonesia, maupun konsumen dan pelaku usaha warga negara Indonesia yang berada di Indonesia. Keberlakuan UUPK bagi konsumen dan pelaku usaha Indonesia yang berada di luar wilayah Hukum Negara RI, harus mengantisipasi terwujudnya ASEAN Communities. Antisipasi tersebut dapat dilakukan dengan mencantumkan suatu kaidah penunjuk, manakala ASEAN Communities kelak mengatur penyelesaian perselisihan hukum (conflict of laws) melalui salah satu cara, yaitu melalui pilihan hukum atau harmonisasi.

Berkenaan dengan penyelesaian sengketa konsumen yang dilakukan melalui BPSK sebagaimana telah diuraikan dalam pembahasan sebelumnya, dapat dikemukakan adanya berbagai kekurangan atau kelemahan. Dalam konteks sengketa konsumen yang tidak jarang nilai secara finansial kecil, proses penyelesaian yang lama, birokratis dan tidak murah tentu jauh dari nilai keadilan dan kemanfaatan terutama bagi konsumen. Oleh karenanya diperlukan optimalisasi melalui upaya perubahan terhadap konsep, sistem hukum dan implementasi peran BPSK sebagai lembaga alternatif penyelesaian sengeta konsumen di luar pengadilan. Sistem hukum yang tidak efektif tentu berakibat pada terhambatnya tujuan hukum yang akan dicapai. Meuwissen menyebutnya sebagai 'keberlakuan sosial atau faktual' yaitu berkenaan dengan efektivitas (wirksampkeit) dari kaidah hukum. Sedangkan Bruggink menyebutnya sebagai 'keberlakukan empiris atau faktual' yaitu jika para warga masyarakat untuk siapa kaidah hukum itu berlaku, mematuhi kaidah hukum itu.

Dalam konteks efektivitas hukum, menarik untuk diperhatikan pendapat dari Paul dan Dias sebagaimana dikutip oleh Esmi Warassih yang mengajukan 5 syarat sebagai berikut: ${ }^{9}$

1. Mudah tidaknya makna aturan-aturan hukum itu untuk ditangkap dan dipahami;

2. Luas tidaknya kalangan di dalam masyarakat yang mengetahui isi aturan-aturan hukum yang bersangkutan;

3. Efisien dan efektif tidaknya mobilisasi aturan-aturan hukum;

4. Adanya mekanisme penyelesaian sengketa yang tidak hanya mudah dijangkau dan dimasuki oleh setiap warga masyarakat, melainkan juga harus cukup efektif dalam menyelesaikan sengketa-sengketa;

5. Adanya anggapan dan pengakuan yang merata di kalangan warga masyarakat bahwa aturan-aturan dan pranatapranata hukum itu memang sesungguhnya berdaya kemampuan yang efektif.

Secara substansial, persyaratan yang diajukan oleh Paul dan Dias tersebut sesuai untuk diterapkan dalam upaya optimalisasi BPSK, dalam kerangka pembangunan sistem hukum perlindungan konsumen. Pertama, dari aspek substansi aturan, UUPK beserta seluruh aturan pelaksanaannya perlu ditinjau ulang terutama pengaturan tentang mekanisme penyelesaian sengketa konsumen agar tidak bersifat kaku, sempit dan inkonsisten tanpa memperhatikan hukum yang hidup dalam masyarakat. Apabila diletakkan dalam konteks sistem hukum Friedman, materi UUPK ini adalah subsistem

${ }^{9}$ Ibid, Hlm. 19. 
substance, yaitu peraturan dan ketentuan mengenai bagaimana institusi-institusi harus berperilaku. Dimungkinkannya pelaku usaha mengajukan keberatan atas putusan BPSK ke Pengadilan Negeri serta perlunya penetapan eksekusi dari Pengadilan Negeri, selain tidak konsisten dengan sifat putusan BPSK yang final dan mengikat, sejatinya juga tidak sejalan dengan tujuan pembentukan BPSK yakni menyelesaikan sengketa secara musyawarah untuk mencapai mufakat. Kultur hukum masyarakat Indonesia pada dasarnya didominasi oleh kultur penyelesaian sengketa dengan cara mengelola sendiri sengketa tersebut, yaitu secara musyawarah untuk mencapai mufakat. Penyelesaian sengketa dengan cara musyawarah untuk mencapai mufakat dapat dilakukan apabila para pihak berada dalam kesetaraan, sehingga tidak diperlukan campur tangan pihak ketiga. Cara penyelesaian sengketa secara musyawarah untuk mencapai mufakat dapat mengurangi rasa permusuhan di antara para pihak yang bersengketa. Kultur dan cara penyelesaian sengketa yang demikian sesuai dengan nilai-nilai luhur yang terkandung dalam Pancasila, antara lain nilai kekeluargaan dan musyawarah.

Berdasarkan pandangan-pandangan tersebut, pengaturan tentang penyelesaian sengketa konsumen melalui BPSK harus diarahkan pada penyelesaian secara musyawarah sebagai kultur dasar masyarakat Indonesia. Putusan BPSK yang didasarkan pada hasil musyawarah harus ditegaskan bersifat final dan mengikat serta dapat langsung dieksekusi.

Kedua, dari aspek kelembagaan. Konsep BPSK sebagai small claim tribunal/small claim court yang harus dibentuk di seluruh kota/kabupaten harus dikembalikan pada roh utama lembaga tersebut. BPSK merupakan perpaduan antara lembaga ADR (alternative dispute resolution)/Alternatif Penyelesaian Sengketa (APS) yang simpel dan fleksibel, dan lembaga Pengadilan yang memiliki otoritas dalam membuat putusan. Dalam pandangan Satjipto Rahardjo, untuk mewujudkan tujuan hukum diperlukan organisasi yang memiliki otonomi agar dapat menjalankan fungsinya. Otonomi tersebut diperlukan agar dapat mengelola sumber-sumber daya yang terdiri dari (a) sumber daya manusia, (b) sumber daya fisik, (c) sumber daya keuangan, (d) sumber daya lainnya. ${ }^{10}$ Dalam konteks sistem hukum Friedman, kelembagaan BPSK ini adalah subsistem structure yang disebut sebagai kerangka badan (skeleton), tubuh institusional dari sistem tersebut (the institutional body of the system), tulang-tulang keras (rigid bones) yang menjaga agar proses mengalir dalam batasbatasnya (keep the process flowing withing bounds). Oleh karena itu BPSK harus didorong menjadi lembaga penyelesaian sengketa konsumen di luar pengadilan yang kuat dan dapat dipercaya.

Ketiga, menyangkut cara penerapan hukum anggota BPSK perlu terus didorong agar tidak terjebak pada cara-cara berhukum yang sangat legal-positivistik. Anggota BPSK perlu memiliki pandangan 'skeptisisme peraturan' seperti dikemukakan oleh Hart. Hal ini disebabkan karakteristik sengketa konsumen seringkali bersifat khas dan kompleks sehingga memerlukan cara penyelesaian yang tidak kaku dan terbelenggu bunyi undang-undang, apalagi dengan substansi UUPK yang terbatas dan beberapa di antaranya bermasalah. Dalam hal ini menarik untuk diperhatikan pandangan Satjipto Rahardjo tentang Hukum Progresif. Satjipto Rahardjo mengatakan bahwa Hukum Progresif mengangkat faktor manusia penegak hukum sebagai penentu penting dalam jalannya hukum. Hukum Progresif tidak melihat cara berhukum sebagai sesuatu yang 'datar', melainkan mengandung muatan modalitas yang kuat. Modalitas tersebut adalah compassion, emphaty, sincerety, dan dare. Sebagai konsekuensi dari pardigma 'hukum untuk

10 Satjipto Rahardjo, Penegakan Hukum Suatu Tinjauan Yuridis, Yogyakarta: Genta Publishing, 2009, Hlm. 23. 
manusia', maka penegakan hukum tidak boleh bersifat datar-datar saja, melainkan penuh dengan keterlibatan nurani untuk melindungi dan melayani manusia. Oleh karenanya penulis mengusulkan agar akademisi hukum menjadi salah satu unsur dalam keanggotaan BPSK, agar dapat memberikan perspektif yang lebih luas dalam memandang hukum bukan hanya yang tertulis dalam undang-undang saja (law as what in the books), melainkan juga hukum sebagai realitas yang hidup dalam masyarakat (law in action). ${ }^{11}$

Keempat, menyangkut budaya hukum/kultur hukum. Friedman dalam buku On Legal Development sebagaimana dikutip oleh Satjipto Rahardjo menjelaskan bahwa kultur hukum dirumuskan sebagai sikap-sikap dan nilai-nilai yang berhubungan dengan hukum bersamasama dengan sikap-sikap dan nilai-nilai yang berkait dengan tingkah laku yang berhubungan dengan hukum dan lembagalembaganya, baik secara positip maupun negatip. Sementara dalam buku The Legal System, Friedman menyebut legal culture sebagai kekuatan-kekuatan sosial yang menggerakkan hukum (social forces are constantly at work on the law), dan merupakan elemen sikap dan nilai sosial (the element of social attitude and value). Dalam hubungan dengan pranata yang akan dipakai oleh suatu masyarakat dalam menyelesaikan sengketa, Chambliss mengemukakan bahwa apabila tujuannya adalah hendak merukunkan para pihak yang bersengketa, maka lebih ditekankan pada cara-cara mediasi dan kompromi. Dengan demikian, baik konsumen maupun pelaku usaha harus terus didorong dan diyakinkan bahwa BPSK merupakan alternatif penyelesaian sengketa yang adil, efektif dan efisien. ${ }^{12}$

\section{B. FAKTOR PENGHAMBAT OPTIMALISASI}

DALAM BADAN

\footnotetext{
11 Satjipto Rahardjo, Menggagas Hukum Progresif Indonesia, Yogyakarta: Pustaka Pelajar, 2006, Hlm. 57.

12 Ibid., Hlm. 58.
}

\section{PENYELESAIAN \\ SENGKETA \\ KONSUMEN (BPSK) TERHADAP SENGKETA PINJAMAN KREDIT KENDARAAN BERMOTOR DI KOTA BOGOR DAN KABUPATEN BOGOR BERDASARKAN UNDANG-UNDANG NOMOR 8 TAHUN 1999 TENTANG PERLINDUNGAN KONSUMEN}

Hak dan kewajiban konsumen dan pelaku usaha telah diatur dalam UUPK. Pada praktek transaksional antara konsumen dengan pelaku usaha masih sering ditemukan terjadi pelanggaran terhadap hak-hak konsumen. Beberapa contoh kasus sebagaimana telah diuraikan pada latar belakang masih terus terjadi sampai saat ini. Apabila demikian kondisinya, potensi sengketa antara konsumen dengan pelaku usaha akan terbuka lebar. Meskipun telah diterbitkan UUPK, hal ini bukan berarti masalah perlindungan terhadap konsumen sudah selesai, khususnya dalam penyelesaian sengketa antara konsumen dengan pelaku usaha. Dalam hal ini hukum harus dilihat sebagai suatu sistem yang terdiri dari tiga komponen sebagaimana dikemukakan oleh Lawrence M. Friedman, yakni legal substance (aturan-aturan dan normanorma), legal structure (institusi atau penegak hukum), dan legal culture (budaya hukum meliputi ide, sikap, kepercayaan, harapan dan pandangan). Ketiga komponen dalam sistem hukum tersebut saling terkait dan sangat mempengaruhi bekerjanya hukum. ${ }^{13}$

Menurut Az. Nasution, sengketa konsumen merupakan sengketa antara konsumen dengan pelaku usaha (publik atau privat) tentang produk konsumen, barang dan/atau jasa konsumen tertentu. Sedangkan Shidarta mengemukakan bahwa sengketa konsumen pada dasarnya merupakan sengketa berkenaan dengan pelanggaran hak-hak konsumen, yang

13 Lawrence M. Friedman, The Legal System. A Social Science Perspective, New York: Russell Sage Foundation, 1975, P. 19. 
lingkupnya mencakup segi hukum keperdataan, pidana maupun tata negara. ${ }^{14}$

UUPK sendiri tidak memberikan batasan secara eksplisit tentang pengertian sengketa konsumen, namun istilah 'sengketa konsumen' dapat ditemukan pada beberapa bagian dari UUPK, yaitu:

1. Penyebutan sengketa konsumen sebagai bagian dari sebutan institusi administrasi negara yang mempunyai kewengan menyelesaikan sengketa antara pelaku usaha dengan konsumen, dalam hal ini Badan Penyelesaian Sengketa Konsumen (BPSK), yang terdapat dalam Pasal 1 angka 11 jo. Bab XI UUPK;

2. Penyebutan sengketa konsumen menyangkut tata cara atau prosedur penyelesaian sengketa terdapat pada Bab X tentang Penyelesaian Sengketa. Pada bab ini digunakan penyebutan sengketa konsumen secara konsisten yaitu Pasal 45 ayat (2) dan Pasal 48 UUPK.

Bernadette M. Waluyo menyatakan bahwa pengertian sengketa konsumen memang tidak secara tegas terdapat dalam UUPK namun dapat disimpulkan dari ketentuan Pasal 23 UUPK. ${ }^{15}$ Sengketa konsumen terjadi apabila pelaku usaha menolak dan/atau tidak memberi tanggapan dan/atau tidak memenuhi ganti rugi atas tuntutan konsumen sebagaimana diatur dalam Pasal 19 UUPK. Dengan demikian pengertian sengketa konsumen adalah sengketa antara konsumen dengan pelaku usaha karena pelaku usaha menolak, dan/atau tidak memberikan tanggapan, dan/atau tidak memenuhi ganti rugi atas tuntutan konsumen sebagaimana diatur dalam Pasal 19 UUPK.

Menurut Az. Nasution, penyelesaian sengketa konsumen dapat dilakukan melalui cara-cara perdamaian atau musyawarah (mediasi) maupun melalui lembaga (instansi) yang berwenang.

${ }^{14}$ Az. Nasution, Op.Cit., Hlm. 55.

15 Bernadette M. Waluyo, Hukum Perlindungan Konsumen, Jakarta: Rajawali Pers, 1997, HIm. 11.
Penyelesaian sengketa melalui instansi yang berwenang dapat dilakukan dengan: ${ }^{16}$

a. Mengadukan atau melaporkan perihal ganggunan atas kepentingan konsumen melalui instansi pemerintah terkait, yang berdasarkan hukum publik mempunyai kewenangan administratif terhadap perusahaanperusahaan dalam lingkup wewenangnya.

b. Memasukkan gugatan perdata ganti rugi karena ingkar janji atau perbuatan melawan hukum, tergantung dari hubungan konsumen dengan pelaku perbuatan yang merugikannya, kepada pengadilan yang berwenang.

Ketika terjadi sengketa konsumen, salah satu elemen dalam perlindungan konsumen adalah penyelesaian sengketa konsumen yang adil. Pasal 4 UUPK menyatakan bahwa konsumen berhak mendapatkan advokasi, perlindungan dan upaya penyelesaian sengketa secara patut. Pasal 23 UUPK secara tegas mengatur bahwa penyelesaian sengketa konsumen dapat dilakukan melalui jalur litigasi (pengadilan) maupun non litigasi (di luar pengadilan). Setiap konsumen yang dirugikan dapat menggugat pelaku usaha melalui lembaga yang bertugas menyelesaikan sengketa antara konsumen dan pelaku usaha, atau melalui peradilan yang berada di lingkungan peradilan umum. Penyelesaian sengketa konsumen dapat ditempuh melalui pengadilan atau di luar pengadilan berdasarkan pilihan sukarela para pihak yang bersengketa.

Apabila telah dipilih upaya penyelesaian sengketa konsumen di luar pengadilan, gugatan melalui pengadilan hanya dapat ditempuh apabila upaya tersebut dinyatakan tidak berhasil oleh salah satu pihak atau oleh para pihak yang bersengketa (Pasal 45 ayat (4)). Ketentuan pasal ini memungkinkan mengajukan gugatan melalui pengadilan ketika penyelesaian melalui BPSK dianggap tidak berhasil. Persoalannya justru pada frasa

\footnotetext{
${ }^{16}$ Az. Nasution, Op.Cit., Hlm. 56.
} 
'tidak berhasil', karena bisa disalahgunakan oleh pihak yang merasa dirugikan dengan putusan BPSK lalu secara sepihak menyatakan penyelesaian melalui BPSK 'tidak berhasil'.

Gugatan atas pelanggaran pelaku usaha dapat dilakukan oleh: (a) seorang konsumen yang dirugikan atau ahli waris yang bersangkutan; (b) sekelompok konsumen yang mempunyai kepentingan yang sama; (c) lembaga perlindungan konsumen swadaya masyarakat yang memenuhi syarat, yaitu berbentuk badan hukum atau yayasan, yang dalam anggaran dasarnya menyebutkan dengan tegas bahwa tujuan didirikannya organisasi tersebut adalah untuk kepentingan perlindungan konsumen dan telah melaksanakan kegiatan sesuai dengan anggaran dasarnya; (d) pemerintah dan/atau instansi terkait apabila barang dan/atau jasa yang dikonsumsi atau dimanfaatkan mengakibatkan kerugian materi yang besar dan/atau jumlah korban yang tidak sedikit. Gugatan yang diajukan oleh sekelompok konsumen, lembaga perlindungan konsumen swadaya masyarakat atau pemerintah diajukan kepada peradilan umum (Pasal 46 ayat (2)). Ini artinya gugatan tersebut tidak dapat diajukan melalui BPSK, atau juga dapat dikatakan bahwa BPSK hanya menerima gugatan dari seorang konsumen atau ahli warisnya. Jadi gugatan yang diajukan oleh seorang konsumen atau ahli warisnya dapat diajukan baik melalui peradilan umum maupun BPSK.

Pasal 10 ayat (1) UU No. 48 Tahun 2009 tentang Kekuasaan Kehakiman menentukan: "Pengadilan dilarang menolak untuk memeriksa, mengadili, dan memutus suatu perkara yang diajukan dengan dalih bahwa hukum tidak ada atau kurang jelas, melainkan wajib untuk memeriksa dan mengadilinya". Ketentuan ini mengandung asas bahwa penyelesaian sengketa harus dilakukan badan peradilan negara. Hal ini dimaksudkan untuk menghindari penyelesaian sengketa dengan cara main hakim sendiri (eigenrichting) yang justru menimbulkan sengketa baru.

Namun demikian, Pasal 10 ayat (2) UU Kekuasaan Kehakiman menentukan, "Ketentuan sebagaimana dimaksud pada ayat (1) tidak menutup usaha penyelesaian perkara perdata secara perdamaian". Berdasarkan ketentuan Pasal 10 ayat (2) ini, pihak-pihak yang bersengketa dibenarkan menurut hukum untuk menyelesaikan sengketanya tanpa harus melalui badan peradilan negara sepanjang menggunakan pranata/lembaga perdamaian. Penyelesaian sengketa secara perdamaian dapat dilakukan langsung oleh pihak-pihak yang sengketa maupun dengan perantaraan pihak ketiga yang netral (mediator).

Penyelesaian sengketa konsumen yang dilakukan di luar pengadilan, diselenggarakan untuk mencapai kesepakatan mengenai bentuk dan besarnya ganti rugi dan/atau mengenai tindakan tertentu untuk menjamin tidak akan terjadi kembali atau tidak akan terulang kembali kerugian yang diderita konsumen (Pasal 47). Ketentuan ini mengarah pada penyelesaian dengan mekanisme konsiliasi dan mediasi karena bertujuan untuk mencapai kesepakatan. Hal ini rancu apabila dikaitkan dengan penyelesaian sengketa konsumen melalui BPSK, karena di dalam BPSK selain konsiliasi dan mediasi juga dimungkinkan mekanisme arbitrase.

Badan Penyelesaian Sengketa Konsumen membentuk majelis dalam jumlah ganjil dan sedikit-dikitnya 3 orang, serta dibantu oleh seorang panitera (Pasal 54 ayat (1) dan (2)) untuk menangani dan menyelesaikan sengketa konsumen. BPSK wajib mengeluarkan putusan paling lambat dalam waktu 21 hari kerja setelah gugatan diterima (Pasal 55), dan putusan tersebut bersifat final dan mengikat (Pasal 54 ayat (3)). Dalam Penjelasan Pasal 54 ayat (3) disebutkan bahwa yang dimaksud dengan putusan majelis bersifat final adalah bahwa dalam BPSK tidak ada upaya banding dan kasasi. 
Berdasarkan Pasal 40 Keputusan Menteri Perindustrian dan Perdagangan No. 350/MPP/Kep/12/2001 tentang Pelaksanaan Tugas dan Wewenang Badan Penyelesaian Sengketa Konsumen, putusan BPSK dapat berupa: (a) perdamaian; (b) gugatan ditolak; atau (c) gugatan dikabulkan. Dalam hal gugatan dikabulkan, amar dalam amar putusan ditetapkan kewajiban yang harus dilakukan oleh pelaku usaha yakni berupa :

a. Pemenuhan ganti rugi yang dapat berupa (a) pengembalian uang; (b) pengantian barang dan/atau jasa yang sejenis atau setara nilainya; atau (c) perawatan kesehatan dan/atau pemberian santunan; dan/atau

b. Sanksi administratif berupa penetapan ganti rugi paling banyak $\mathrm{Rp}$ 200.000.000 (dua ratus juta rupiah).

Setelah persidangan selesai dan majelis telah mengeluarkan putusan, Ketua BPSK memberitahukan putusan majelis secara tertulis kepada alamat konsumen dan pelaku usaha yang bersengketa selambatlambatnya 7 (tujuh) hari kerja sejak putusan dibacakan. Dalam waktu 14 (empat belas) hari kerja terhitung sejak putusan BPSK diberitahukan, konsumen dan pelaku usaha yang bersengketa wajib menyatakan menerima atau menolak putusan BPSK. Pelaku usaha atau konsumen yang menolak putusan BPSK dapat mengajukan keberatan kepada Pengadilan Negeri selambat-lambatnya dalam waktu 14 (empat belas) hari terhitung sejak putusan BPSK diberitahukan. Apabila pelaku usaha menyatakan menerima putusan BPSK, maka pelaku usaha wajib melaksanakan putusan tersebut selambat-lambatnya dalam waktu 7 (tujuh) hari terhitung sejak menyatakan menerima putusan BPSK.

Sedangkan apabila pelaku usaha menolak putusan BPSK tetapi tidak mengajukan keberatan sampai batas waktu pengajuan keberatan terlampaui, maka pelaku usaha dianggap menerima putusan dan wajib melaksanakan putusan tersebut selambat-lambatnya 5 (lima) hari kerja setelah batas waktu mengajukan keberatan dilampaui. Namun apabila pelaku usaha tetap tidak menjalankan kewajibannya tersebut, maka BPSK menyerahkan putusan tersebut kepada penyidik untuk melakukan penyidikan sesuai dengan ketentuan perundang-undangan yang berlaku.

Pasal 54 dan 57 UUPK serta Pasal 42 Keputusan Menteri Perindustrian dan Perdagangan No. 350/MPP/Kep/12/2001 tentang Pelaksanaan Tugas dan Wewenang Badan Penyelesaian Sengketa Konsumen menyatakan bahwa putusan BPSK merupakan putusan yang bersifat final dan telah mempunyai kekuatan hukum yang tetap, dan terhadap putusan tersebut dimintakan penetapan eksekusi oleh BPSK kepada Pengadilan Negeri di tempat konsumen dirugikan. Ketentuan tentang permintaan penetapan eksekusi ini, menurut R. Subekti, sebagai konsekuensi arbitrase sebagai peradilan swasta. Namun permohonan penetapan eksekusi ini hanya terhadap putusan arbitrase yang tidak dilaksanakan secara sukarela oleh salah satu pihak. ${ }^{17}$

Pelaku usaha wajib melaksanakan putusan BPSK paling lambat 7 hari kerja sejak menerima putusan tersebut (Pasal 56 ayat (1)). Tetapi, para pihak dapat mengajukan keberatan kepada Pengadilan Negeri paling lambat 14 hari kerja setelah menerima pemberitahuan putusan tersebut. Apabila ada pihak yang mengajukan keberatan, maka Pengadilan Negeri wajib mengeluarkan putusannya dalam waktu paling lambat 21 hari sejak menerima keberatan. Terhadap putusan pengadilan tingkat pertama tersebut, para pihak masih dapat mengajukan upaya hukum kasasi ke Mahkamah Agung dalam waktu 14 hari, dan Mahkamah Agung wajib mengeluarkan putusan paling lambat 30 hari sejak menerima permohonan kasasi.

Dimungkinkannya upaya hukum banding dan kasasi dalam proses penyelesaian sengketa konsumen melalui

${ }^{17}$ R. Subekti, Op.Cit., Hlm. 17. 
BPSK menunjukkan adanya inkonsistensi, yakni ketidakkonsistenan antara Penjelasan Pasal 54 ayat (3) dengan rumusan Pasal 58 UUPK. Penjelasan Pasal 54 ayat (3) menyatakan bahwa yang dimaksud dengan putusan majelis (BPSK) bersifat final adalah bahwa dalam BPSK tidak ada upaya banding atau kasasi. Akan tetapi, Pasal 58 UUPK menyatakan bahwa terhadap putusan Pengadilan Negeri yang memeriksa keberatan dari pihak yang mengajukan keberatan, dapat diajukan kasasi ke Mahkamah Agung.

Dalam konteks penerapan hukum, pengaruh kekuatan-kekuatan sosial tidak dapat dihindari. Gustav Radbruch mengemukakan bahwa terdapat 3 (tiga) nilai dasar hukum, yaitu keadilan, kegunaan (kemanfaatan) dan kepastian hukum. Hubungan ketiga nilai tersebut merupakan suatu ketegangan satu terhadap yang lain (spannungsverhaltnis). Ketentuan UUPK tentang sifat putusan BPSK yang inkonsisten tentu menimbulkan ketidakpastian hukum. Ketidakpastian hukum ini berimbas pada nilai keadilan dan kemanfaatan, terutama bagi konsumen. Nilai kemanfaatan akan mengarahkan hukum pada pertimbangan kebutuhan masyarakat pada suatu hal tertentu, sehingga hukum benar-benar mempunyai peranan yang nyata bagi masyarakat.

Salah satu fungsi sistem hukum yang dikemukakan oleh Friedman adalah sebagai "the settlement of dispute", menyelesaikan sengketa yang timbul dalam masyarakat. Mendasarkan pada pendapat ini, maka interaksi antara UUPK, pemerintah dan BPSK serta kesempatan bagi konsumen utuk menyelesaikan sengketanya melalui BPSK menjadi sebuah sistem dalam 'melaksanakan' hukum. Ketidaksempurnaan atau ketiadaan salah satu sub sistem, dalam hal ini BPSK, tentu akan mengganggu berjalannya sistem tersebut secara keseluruhan. Akibatnya tujuan hukum yang diharapkan tidak akan tercapai.
Pembentukan BPSK menurut UUPK menjadi tanggung jawab pemerintah. Menurut pandangan William B. Chambliss dan Robert B. Seidman, tindakan apapun yang akan diambil baik oleh pembuat undang-undang, pemegang peran serta lembaga-lembaga penegak hukum selalu berada dalam kompleksitas kekuatankekuatan sosial, ekonomi, politik, budaya dan sebagainya. Pengaruh-pengaruh tersebut telah dimulai sejak pembentukan undang-undang sampai pada penegakan dan penerapan sanksi. Dengan kata lain sifat ketergantungan terhadap pemerintah dalam hal pembentukan BPSK sangat tinggi. Berbagai pengaruh ekonomi, sosial, politik dan budaya memiliki andil dalam pengambilan keputusan pemerintah.

BPSK merupakan salah satu institusi/lembaga penting yang bertugas untuk menyelesaikan sengketa konsumen di luar Pengadilan. Apabila hukum dipandang sebagai institusi, Paul Bohanan sebagaimana dikutip oleh Lawrence $F$. Friedman menyatakan bahwa "...that legal institution are the essence of law. An istitution is legal if people in a society use it to settle dispute..." Pendapat ini ingin menegaskan bahwa institusiinstitusi/lembaga-lembaga hukum merupakan pilar penting dari hukum itu sendiri, apalagi lembaga-lembaga hukum yang mempunyai wewenang untuk menyelesaikan sengketa dalam masyarakat. Apabila justru pemerintah sendiri yang 'membangkang' dari perintah undang-undang tentu tidak bisa dipahami secara akal sehat. Undang-Undang Perlindungan Konsumen jelas bertujuan untuk memberikan perlindungan kepada konsumen, tetapi pemerintah yang bertanggungjawab terhadap hal tersebut justru abai.

Situasi yang melingkupi saat penyusunan UUPK dapat dijelaskan dengan menggunakan hubungan sibernetik yang dikembangkan dari peta Talcott Parsons. Hubungan sibernetik menjelaskan bahwa sub sistem ekonomi memiliki tingkat energi tinggi yang akan mempengaruhi 
(mengkondisikan) sub sistem politik, sosial dan budaya. Ketika hukum merupakan bagian dari sub sistem soaial maka hukum akan sangat dipengaruhi oleh sub sistem ekonomi dan politik. Hubungan sibernetik antara sub-sub sistem dalam masyarakat berlangsung melalui proses arus informasi dari sub sistem dengan tingkat informasi tinggi kepada yang rendah. Sebaliknya, sub sistem dengan tingkat informasi yang lebih tinggi justru dikondisikan oleh sub sistem yang lebih rendah kemampuannya untuk memberikan informasi. Budaya merupakan sub sistem dengan tingkat informasi tinggi yang berfungsi mengontrol sub sistem di bawahnya, yaitu sub sistem sosial, politik dan ekonomi. Sebaliknya ekonomi merupakan sub sistem yang memiliki tingkat energi tinggi yang mempengaruhi kondisi sub sistem di atasnya yaitu sub sistem politik, sosial dan budaya.

Peta Parsons tersebut dikembangkan lebih lanjut oleh Harry C. Bredemeier yang menjelaskan bahwa sistem hukum (pengadilan) memiliki fungsi adaptif dan proses pengintegrasian berbagai kepentingan. Benturan kepentingan di berbagai bidang memberikan isyarat kepada sub sistem sosial (diwakili oleh hukum/pengadilan) agar sengketa yang terjadi diselesaikan. Luaran dari penyelesaian ini berupa penertiban terhadap hubungan kepentingan yang tidak serasi, sehingga kepentingan yang berbenturan bisa diorganisasi kembali menjadi tertib. Pengorganisasian ini bisa berupa penegasan mengenai hak-hak, kewajiban-kewajiban, pertanggunjawaban, penggantian kerugian dan sebagainya. ${ }^{18}$

Selain mengenai keberadaan BPSK, beberapa kendala yang melingkupi BPSK antara lain mengenai peraturan perundang-undangan dan sumber daya. Sebagai sebuah lembaga yang mirip dengan Small Claim Tribunal/Small Claim Court di negara-negara common law, BPSK justru terbelenggu dengan pengaturan yang sangat rigid dalam UUPK. Bahkan beberapa pasal UUPK justru saling bertentangan, misalnya ketentuan Pasal 54 ayat (3) yang menyatakan bahwa putusan BPSK bersifat final dan mengikat tetapi dalam Pasal 58 memberikan ruang bagi pihak yang tidak puas terhadap putusan BPSK dapat mengajukan keberatan ke Pengadilan Negeri dan bahkan bisa mengajukan kasasi ke Mahkamah Agung.

Kendala sumber daya meliputi baik sumber daya manusia maupun infrastruktur dan anggaran. Sebagian besar anggota BPSK masih berpegang pada cara berhukum yang legal-positivistik, sangat kaku dan normatif-sempit dalam membaca teks undang-undang. Hart menggunakan istilah 'skeptisisme-peraturan' untuk menjelaskan bahwa peraturan yang berlaku masih harus diragukan. Oleh karenanya, dalam setiap sistem hukum terbuka ruang yang luas untuk melakukan diskresi bagi para petugas hukum agar standar-standar yang awalnya kabur menjadi pasti dalam menyelesaikan ketidakpastian undang-undang, atau dalam menjabarkan dan memerinci peraturanperaturan yang isinya hanya secara garis besar. Dalam penyelesaian sengketa konsumen, dimana posisi konsumen biasanya sangat lemah dan berhadapan dengan pelaku usaha yang kuat, aspekaspek nonyuridis seperti aspek ekonomi, aspek psikologi dan aspek budaya sangat penting untuk diperhatikan.

Berkenaan dengan aspek infrastruktur dan anggaran, dalam praktek hal ini sangat tergantung pada pemerintah daerah (kota/kabupaten) masing-masing karena penganggaran BPSK dimasukkan dalam APBD. Umumnya masalah penyelesaian sengketa konsumen tidak menjadi prioritas dalam APBD sehingga anggarannya relatif kecil. Pemerintah sebagai institusi pembentuk BPSK rasanya kurang serius dalam pengembangan BPSK sehingga benar-benar bisa berjalan optimal. Kesan umum yang nampak baik pemerintah pusat maupun daerah lebih sibuk mengejar dan melayani investor dari pada memikirkan 
kepentingan publik termasuk hak-hak konsumen.

Menurut ketentuan UUPK keanggotan BPSK terdiri dari 3 (tiga) unsur yaitu unsur pemerintah, pelaku usaha (organisasi pelaku usaha) dan konsumen (organisasi konsumen). Bahwa sebagian besar anggota BPSK masih berpandangan legalpositivistik ketika menyelesaikan sengketa konsumen. Artinya para anggota BPSK memiliki persepsi dogmatis-normatif dalam melihat UUPK. Oleh karenanya, dalam melaksanakan tugas dan kewenangannya, anggota BPSK perlu mulai mengarahkan pandangan pada apa yang dikemukakan oleh Philipe Nonet dan Philip Selznick sebagai hukum responsif, yakni hukum sebagai fasilitator dari respons terhadap kebutuhan sosial dan aspirasi sosial. Apa yang menjadi tujuan hukum dan apa yang harus dilayani oleh aturan hukum tidak selalu tampak, mungkin tersembunyi dan implisit. Pokok yang penting adalah bahwa dalam menentukan arti dari aturanaturan, pertanyaan yang harus diajukan adalah: maksud-maksud apa yang dilayani, nilai-nilai apa dan kepentingan apa yang harus dipertaruhkan.

\section{KESIMPULAN}

Berdasarkan hasil penelitian dan analisis di atas, dapat ditarik kesimpulan sebagai berikut:

1. BPSK Kota Bogor dan Kabupaten Bogor terhadap sengketa pinjaman kredit kendaraan bermotor belum optimal, maka diperlukan upaya-upaya optimalisasi agar BPSK dapat menjadi lembaga penyelesaian sengeta konsumen di luar pengadilan yang cepat, murah dan adil. Upaya optimalisasi BPSK dapat dilakukan melalui perubahan terhadap: Substansi peraturan, kelembagaan BPSK, cara penerapan hukum serta menyangkut budaya hukum.

2. Faktor penghambat optimalisasi BPSK Kota Bogor dan Kabupaten Bogor terhadap sengketa pinjaman kredit kendaraan bermotor, meliputi peraturan perundang-undangan dan sumber daya. BPSK terbelenggu dengan peraturan yang sangat rumit dalam UUPK, bahkan beberapa pasal UUPK justru saling bertentangan. Kendala sumber daya meliputi baik sumber daya manusia maupun infrastruktur dan anggaran.

\section{SARAN}

1. Perlu adanya perubahan-perubahan terhadap kaedah-kaedah yang mengatur Badan Penyelesaian Sengketa Konsumen (BPSK), sehingga BPSK dapat berperan lebih optimal.

2. Agar segera dilakukan revisi UUPK mengenai kompleksnya tugas BPSK sebagai lembaga penyelesaian sengketa, dalam hal pendanaan peneliti menyarankan adanya aturan yang secara tegas dan rinci mengatur mengenai alokasi secara rasional yang seharusnya dialokasikan untuk Badan Penyelesaian Sengketa Konsumen, mengenai Sumber Daya Manusia (SDM) Pemerintah hendaknya memperkuat Sumber Daya Manusia (SDM) dengan memberikan pendidikan yang lebih intensif (mahir) kepada para anggota BPSK, serta adanya keseriusan untuk menumbuhkan kesadaran bagi semua pihak terkait perlindungan konsumen. 


\section{DAFTAR PUSTAKA}

\section{A. Buku}

Az. Nasution, Hukum Perlindungan Konsumen Suatu Pengantar, Cetakan Kedua, Jakarta: Diadit Media, 2002.

Bernadette M. Waluyo, Hukum Perlindungan Konsumen, Jakarta: Rajawali Pers, 1997.

Esmi Warassih, Pranata Hukum Sebuah Telaah Sosiologis, Semarang: Badan Penerbit UNDIP, 2011.

Lawrence M. Friedman, The Legal System. A Social Science Perspective, New York: Russell Sage Foundation, 1975.

Satjipto Rahardjo, Menggagas Hukum Progresif Indonesia, Yogyakarta: Pustaka Pelajar, 2006.

---------, Penegakan Hukum Suatu Tinjauan Yuridis, Yogyakarta: Genta Publishing, 2009.

Subekti, Hukum Perjanjian, Cet. XXI, Jakarta: PT. Intermasa, 2005.

Suherdi Sukandi, Fungsi dan Peranan Dalam Penyelesaian Sengketa Konsumen, Semiloka UUPK dan BPSK Kota Bandung, Bandung 29 Mei 2004.

\section{B. Peraturan Perundang-undangan}

Undang-undang Dasar Negara Republik Indonesia Tahun 1945.

Undang-undang Nomor 8 Tahun 1999 tentang Perlindungan konsumen.

Undang-undang Nomor 30 Tahun 1999 tentang Arbitrase.

Keputusan Menteri Perindustrian dan Perdagangan No. 350/MPP/Kep/12/2001 tentang Pelaksanaan Tugas dan Wewenang Badan Penyelesaian Sengketa Konsumen.

Putusan Kasasi MA Nomor 378 K/Pdt.Sus-BPSK/2012.

\section{Koran}

Kompas, Developer Jangan Bohongi Konsumen, 17/02/2016.

, Kritis Menghadai Trik dagang, 04/03/2016.

Suara Merdeka, Menyoal Kepedulian Konsumen, 07/01/2016, \& Jawa Pos, Janji Indah Itu Hanya Basa-basi, 16/01/2016. 